ANL/EAIS/TM- -3

DE90 006381

ANLIEAIS/TM-3

\title{
Comparison of Surface Meteorological Data Representativeness for the Weldon Spring Transport and Dispersion Modeling Analysis
}

by Michael Lazaro

Environmental Assessment Programs,

Environmental Assessment and Information Sciences Division,

Argonne National Laboratory, 9700 South Cass Avenue, Argonne, Illinois 60439

Jurie 1989

Work sponsored by United States Department of Energy, Oak Ridge Operations Office 


\section{Argonne National Laboratory}

Argonne National - -boratory, with facilities in the states of llinois and Idaho, is owned by the United States government, and operated by the University of Chicago under the provisions of a contract with the Department of Energy

This technical memo is a product of Argonne's Environmental Assessment and Information Sciences (EAIS) Division. For information on the division's scientific and engineering activities, contact:

Director, Environmental Assessment and information Sciences Division

Argonne National Laboratory

Argonne, Illinois 60439-4815

Telephone (708) 972-3759

Presented in this technical memo are preliminary iesults of ongoing work or work that is more limited in scope and depth than that described in formal reports issued by the EAIS Division.

\section{Disclaimer}

This report was prepared as an account of work sponsored by an agency of the United States Government. Neither the United States Government nor any agency thereot, nor any of their employees, makes any warranty, express or implied, or assumes any legal liability or responsibility for the accuracy, completeness, or usefulness of any information, apparatus, product, or process disclosed, or represents that its use would not infringe privately owned rights. Reference herein to any specific commercial product, process, or service by trade name, trademark, manufacturer, or otherwise, does not necessarily constitute or imply its endorsement. recommendation, or favoring by the United States Government or any agency thereof. The views and opinions of authors expressed herein do not necessarily state or reflect those of th jnited States Government or any agency thereof.

Reproduced from the best available copy. Available from the National Technical information Service (NTIS), U.S. Department of Commerce, 5285 Port Royal Road, Springfield, Virginia 2.2161.

NTIS price codes: 


\section{CONTENTS}



ABSTRACT $\ldots \ldots \ldots \ldots \ldots \ldots \ldots \ldots \ldots \ldots \ldots \ldots \ldots \ldots \ldots \ldots \ldots \ldots \ldots \ldots \ldots \ldots$

1 BACKGROUND $\ldots \ldots \ldots \ldots \ldots \ldots \ldots \ldots \ldots \ldots \ldots \ldots \ldots \ldots \ldots \ldots \ldots \ldots \ldots \ldots$

1.1 Purpose $\ldots \ldots \ldots \ldots \ldots \ldots \ldots \ldots \ldots \ldots \ldots \ldots \ldots \ldots \ldots \ldots \ldots \ldots \ldots \ldots \ldots \ldots$

1.2 Potential Pollutant Transport and Dispersion Modeling Constraints ........ 2

1.3 Expected wind Patterns $\ldots \ldots \ldots \ldots \ldots \ldots \ldots \ldots \ldots \ldots \ldots \ldots \ldots \ldots \ldots \ldots \ldots$

2 METHODOLOGY ................................... 5

3 LOCAL SURFACE METEOROLOGY DATA BASE ................. 7

3.1 Station Characteristies $\ldots \ldots \ldots \ldots \ldots \ldots \ldots \ldots \ldots \ldots \ldots \ldots \ldots \ldots \ldots \ldots \ldots$

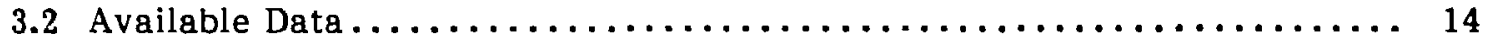

3.3 Stability Classification .............................. 14

4 RESULTS AND DISCUSSION ........................... 19

4.1 Wind Frequency Distributions $\ldots \ldots \ldots \ldots \ldots \ldots \ldots \ldots \ldots \ldots \ldots \ldots \ldots \ldots \ldots \ldots$



5 RECOMMENDATION ............................... 29



\section{FIGURES}

1 Preparation and Processing of Meteorological Data ................. 6

2 Topographic Map of the Weldon Spring Area Showing the Locations of

Four Weather Stations Examined in This Study .................. 8

3 Topography Near the Labadie Power Plant ...................... 9

4 Topography Near the Weldon Spring Chemical Plant and Quarry,

Spirit of St. Louis Airport, and Regional Air Monitoring Station $125 \ldots \ldots \ldots$

$5 \quad$ Views of the LIAP, SSAP, and LPP-100 Stations $\ldots \ldots \ldots \ldots \ldots \ldots \ldots \ldots \ldots$

6 Views of the Weldon Spring site $\ldots \ldots \ldots \ldots \ldots \ldots \ldots \ldots \ldots \ldots \ldots \ldots$

$7 \quad$ Wind Frequency Distribution at the WSCP Station During $1985 \ldots \ldots \ldots$

8 Wind Frequency Distribution at the LPP-100 Station During $1985 \ldots \ldots \ldots \ldots$

9 Wind Frequency Distribution at the LPP-10 Station During $1985 \ldots \ldots \ldots 2$ 


\section{FIGURES (Cont'd)}

10 Wind Frequency Distribution at the LIAP Station During $1985 \ldots \ldots \ldots \ldots \ldots$

11 Seasonal Wind Frequency Distributions at the WSCP Station During 1985

12 Seasonal Wind Frequency Distributions at the LPP-10 Station During 1985

\section{TABLES}

1 Locations and Terrain Features of the Alternative Surface Weather Station Sites

2 Summary of Data Records for the Alternative Surface Weather Stations

3 Initial Estimates of Pasquill Stability Categories .................. 16

4 Final Estimates of Pasquill Stability Categories for Vertical Wind Direction Fluctuations, Adjustirg for Wind Speed . . . . . . . . . . . . . .

5 Final Estimates of Pasquill Stability Categories for Horizontal Wind Direction Fluctuations, Adjusting for Wind Speed

6 Ranking of Data Set Representativeness . 


\section{FOREWORD}

The Weldon Spring site is located near Weldon Spring, Missouri, about $30 \mathrm{mi}$ west of St. Louis. At various times since the 1940s, portions of the site have been used as ordnance works by the U.S. Army and for uranium processing and waste storage facilities by the U.S. Atomic Energy Commission. As a result of these uses, two areas at the site -- the chemical plant and raffinate pits area and the quarry -- are contaminated with chemical and radioactive waste. On July 22, 1987, the U.S. Environmental Protection Agency (EPA) listed the quarry on its National Priorities List. The EPA listed the remainder of the Weldon Spring site on March 13, 1989.

As current owner of the site, the U.S. Department of Energy is conducting the Weldon Spring Site Remedial Action Project under the Surplus Facilities Management Program (SFMP). The major goals of the SFMP are to eliminate potential hazards to the public and the environment that are associateo with contamination at SFMP sites and to make surplus property available for other uses to the extent possible. Remedial actions under the SF MP are conducted in accordance with the National Environmental Policy Act and subject to EPA oversight under the Comprehensive Environmental Response, Compensation, and Liability Act, as amended by the Superfund Amendments and Reauthorization Act.

This report presents the results of an analysis of available meteorological data from stations near the site. Data that are most representative of site conditions are needed to accurately model the transport and dispersion of air pollutants associated with remedial activities. Such modeling will assist the development of mitigative measures. 


\title{
COMPARISON OF SURFACE METEOROLOGICAL DATA REPRESENTATIVENESS FOR THE WELDON SPRING TRANSPORT AND DISPERSION MODELING ANALYSIS
}

by

Michael A. Lazaro

\begin{abstract}
Meteorological data collected at five stations near the Weldon Spring site near St. Charles, Missouri, were evaluated to select data representative of site conditions. Representative data are needed to model the transport and dispersion of pollutants (mainly particulates) associated with proposed remedial activities to remove chemically and radioactively contaminated bulk waste from the quarry. The ranking of data representativeness was based on the stations' proximity to the site, the similarity of terrain at the stations and site, the completeness of data records, and the exposure and height of the stations' instrumentation. The study determined that data from the Weldon Spring chemical plant station best represent conditiors at an area proposed for temporary storage of bulk wastes and that data from the Labadie Power Plant 10-meter tower best represent conditions at the Weldon Spring quarry.
\end{abstract}

\section{BACKGROUND}

\subsection{PURPOSE}

A bulk-waste removal program is proposed for the quarry at the Weldon Spring site near St. Charles, Missouri. The Weldon Spring quarry (WSQ) contains chemically and radioactively contaminated waste -- inciuding soils and sludges, process wastes, rubb!e, drums, structural debris, and equipment -- disposed of by the Army when it operated an ordance works at the site and the Atomic Energy Commission when it operated uranium processing and waste storage facilities at the site. The waste is to be hauled from the WSQ to a temporary storage area (TSA) near the raffinate pits at the old Atomic Energy Commission chemical plant about $6 \mathrm{~km}$ north of the quarry. A feasibility study is being conducted to evaluate the probable effectiveness and potential impacts of remedial activities at the quarry. As part of these evaluations, it is necessary to model meteorological conditions near the quarry, TSA, and proposed haul road between them. Such modeling will illustrate the transport and dispersion of pollutants (primarily particulate matter) associated with removal activities, help predict their downwind concentrations and deposition, and provide guidance for developing strategies for 
minimizing emissions of these pollutants, to protect public health and welfare. Thus, the principal objective of this study is to develop and apply criteria to objectively select the meteorologieal data that most closely represent conditions in and around the WSQ and TSA. Accurately representing these conditions is of key importance to the credible prediction of the spatial and temporal distribution of pollutant concentrations associated with the bulk-waste removal activities.

The analysis criteria used for determining the representativeness of data collected at various weather stations consist of four key elements: (1) proximity of the weather station to the area under consideration, (2) relative complexity of terrain features, (3) exposure of instruments at each station, and (4) completeness and length of data record. Spatial representativeness of dispersion conditions can be affected by terrain complexity and by large distances between the modeled emission source and the measurement point for meteorological data used to drive air dispersion models. The lack of spatial representativeness can adversely affect the accuracy of the predicted pollutant concentrations. Temporal representativeness is a function of the year-to-year or season-to-season variation of conditions at compared station sites.

\subsection{POTENTLAL POLLUTANT TRANSPORT AND DISPERSION CONSTRAINTS}

The selection and application of an appropriate air quality model require careful consideration of site- and pollutant-specific conditions (i.e., complex tertain, large surface water areas, and dense vapors) that can influence the physics and chemistry of transport and dispersion. These conditions can present modeling constraints that should be compared with the limitations of the various models under review. At the Weldon Spring site, the only potentially significant constraint is the complexity of the terrain and the altered surface flows that it can produce.

The amount of solar insolation received over a land surface plays an important role in the local atmospheric stability and wind patterns. The amount of solar energy received over irregular terrain can vary widely with elevation and aspect angle (orientation of the surface with respect to the sun), resulting in differential heating. In addition, mechanical forcing over a rough, irregular surface can alter a wind's direction or increase the overall atmospheric turbulence.

Irregular terrain can produce two general types of locally generated flow systems that can influence pollutant dispersion and transport: (1) thermally generated and mechanically forced surface flows and (2) surface flow alterations by large-scale meteorological systems.

Thermally generated and mechanically forced surface flows arise from differential heating of terrain surfaces and changes in surface features, respectively, that can generate local winds and change local atmospheric stability. Such winds can be divided into three categories:

- Upslope-downslope flows generally are induced by differential heating or cooling of sloped surfaces during the day (upslope) and night (downslope). During clear nights when the prevailing $w$ nd is 
light and as the surface cools by radiation, air immediately adjacent to sloping terrain cools and becomes denser than air at the same elevation but farther from the surface. The denser air tends to drain down the sloped surface (also known as drainage winds). On clear days with light winds, an opposite circulation pattern may develop. Upslope flows, which are less common and not as well marked as downslope flows, are due to the heating of air adjacent to the sun-warmed slopes. Upslope-downslope winds are generally shallow, usually not deeper than $100-200 \mathrm{~m}$.

- Surface temperature inversions are characterized by increasing temperature with height above ground surface. This condition is due primarily to a radiative loss of heat at or near the earth's surface that is greater than that at levels above the surface. Surface inversions often for $m$ in mountain valleys. 1,2

- Mechanically induced turbulence, which is generally produced by abrupt elevation changes, isolated topographic features, and very irregular surfaces. 3,4

As the name implies, surface flow alterations by large-scale meteorological systems are local surface expressions of large weather systems or patterns. These surface flows also can be divided into three categories:

- Separation and decoupling can be induced on the downwind side of a ridge by wind blowing perpendicuiar to it. ${ }^{5}$ The separation can produce a closed eirculation and wake ef fect downwind of the ridge.

- Channeling is produced by the steering of winds by steep valley walls. 6,7

- Lee waves and blocking are generally caused by stable flows around major terrain features. 8 Downwind wave patterns, depending on their height above ground surface, can produce separation or highvelocity surface flows. Blocking is the result of upwind stagnation.

\subsection{EXPECTED WIND PATTERNS}

As noted in Sec. 1.2, the local terrain and its effects on local wind patterns present the only potentially significant constraint on pollutant transport and dispersion modeling at and between the TSA and WSQ. The local terrain in and around the TSA and WSQ could generally be considered irregular (light to moderately sloped) but not complex (mountain or mountain valley terrain). Due to the lack of steep surfaces and the presence of heavily vegetated areas, upslope-downslope surface flows should not be a significant modeling concern. Although surface features can mechanically induce turbulence, the features of the TSA and WSQ terrain are generally not complex enough to make a significant difference in turbulent diffusion of pollutants. 
Large-scale surface flow alterations are also not expected to contribute significantly to ground-level wind and dispersion patterns near the WSQ and TSA. Releases should be too close to the ground to be affected by separation and decoupling, and the gradual valley ridge slope is also expected to minimize such effects. As with inversions, channeling is usually not significant above valley ridges, and changes in terrain in the area are generally not significant enough to generate lee waves and blocking flows. 


\section{METHODOLOGY}

The first task in the review of data representativeness required the identification, acquisition, and review of all readily available surface meteorological data collected within $50 \mathrm{~km}$ of the WSQ and Weldon Spring chemical plant (WSCP). Where possible, digitized data were obtained. Spatial proximity and similarity in terrain features were key to the selection process. Data on surface roughness (e.g., terrain elevations and land use) were obtained from the 7.5-minute series of topographic maps published by the U.S. Geological Survey (USGS). ${ }^{9-12}$ The analysis required at least parer-readable summaries and hourly measurements of wind speed and direction, ambient temperature (from at least one level), and sets of parameters for computing atmospheric stability, e.g., (1) eloud cover, ceiling height, and wind speed; (2) vertical or horizontal wind fluctuations and speed; (3) vertical teinperature gradient; or (4) surface roughness, friction velocity, vertical heat flux, and Monin-Obukov length (a parameter describing surface-layer atmospheric stability). In addition to data collection and comparison, most of the station sites were visited to characterize and compare relative exposure and topography. To the extent possible, instrumentation was also observed.

Figure 1 shows the steps invoived in processing the meteorological data for this analysis, as well as for input to the short-and long-term versions of the Industrial Source Complex (ISC) model. The wind and temperature data were reformatted and initialized for input into a preprocessor program (known as RAMMET). Where cloud cover and ceiling height data were not measured, it was not possible to use the method preferred by the U.S. Environmental Protection Agency (EPA) 13,14 for determining Pasquill stability categories (Turner's method ${ }^{15}$ ). For such situations, EPA guidance provides for the use of site-specific measurements of the standard deviation of vertical $\left(\sigma_{\phi}\right)$ and horizontal $\left(c_{a}\right)$ wind direction fluctuations. Sof tware incorporating this approach (the atmospheric stability converter in Fig. 1) was written to process the data. Substitutions were made for missing data in accordance with the guidance given by the EPA for on-site meteorological programs. ${ }^{13}$ To the extent possible, upper air data (e.g., mixing heights) were also incorporated in to the analysis.

A second meteorological preprocessor (the BEESTAR program) generated a joint frequency distribution (i.e., for different parameters coinciding with the same period of time) for both winds and atmospheric stability. The distributions were used to produce wind roses and as meteorological input for the long-term version of the ISC model. 


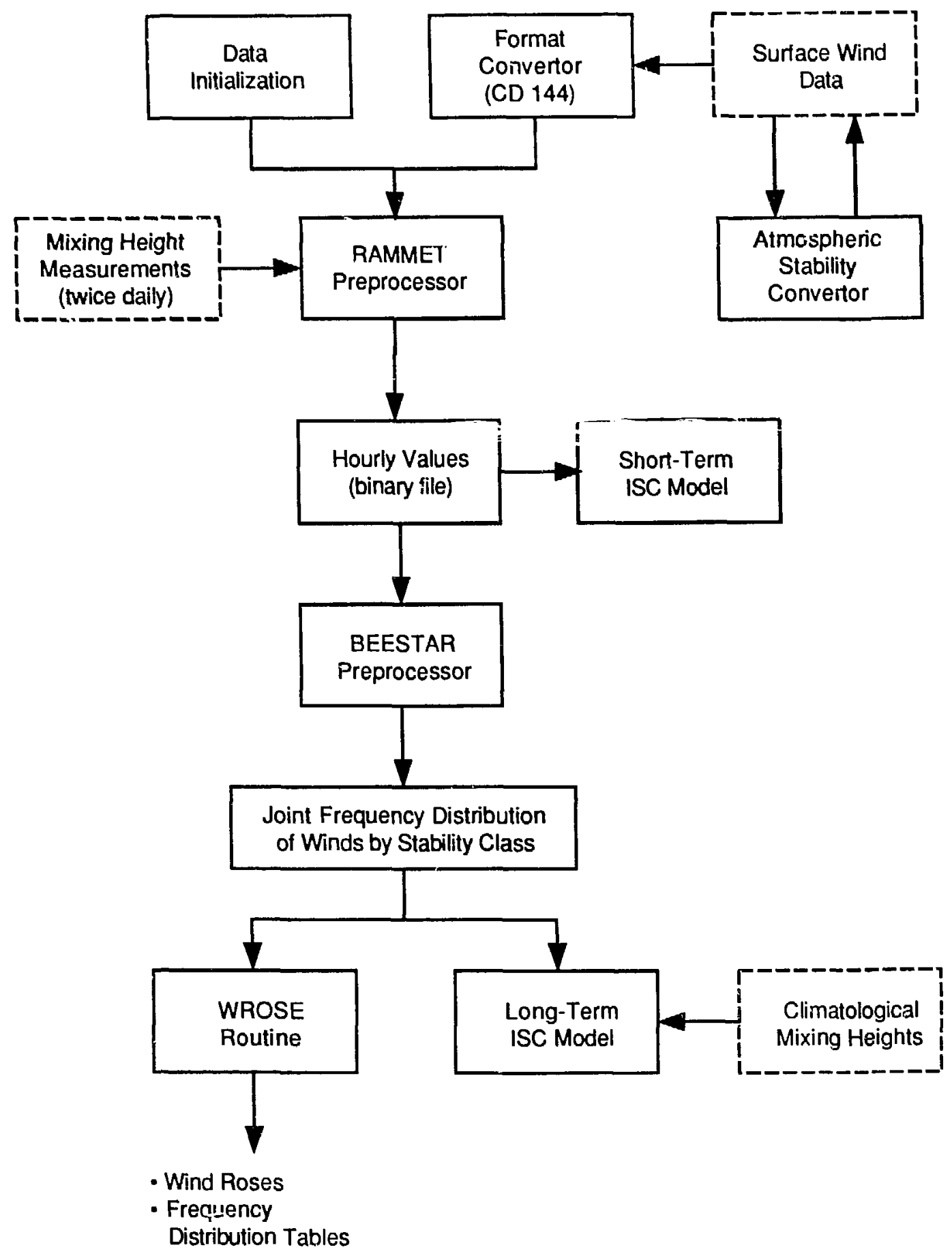

FIGURE 1 Preparation and Processing of Meteoroiogical Data 


\section{LOCAL SURFACE METEOROLOGICAL DATA BASE}

\subsection{STATION CHARACTERISTICS}

Meteorological surface data were available in digitized, computer printout, or microfiche format from weather stations at five locations in the Weldon Spring area:

1. Lambert International Airport (LIAP), which is a serond-order National Weather Service (NWS) station with a 10 -m tower;

2. The WSCP, which had a 10-m tower;

3. Labadie Power Plant (LPP), which has two towers -- $10 \mathrm{~m}$ (LPP-10) and $100 \mathrm{~m}$ (LPP-100) (with 50- and 85-in levels);

4. Spirit of St. Louis Airport (SSAP), which has a $10-\mathrm{m}$ tower atop a former flight control tower; and

5. Regional Air Monitoring System (RAMS) station 125, which had a 30-m tower.

Figure 2 shows the locations of four of the station sites; ${ }^{9-12}$ the LIAP station is not within the map borders at the scale used for the figure. In addition, Figs. 3 and 4 show enlarged portions of Fig. 2 to facilitate topography comparison. Table 1 lists the specifies of the stations' locations, as well as terrain descriptions.

The weather stations examined in this study were operated for various purposes and at various times. Some are still operational, while others have been shut down and dismantled. The LIAP station is an NWS Contract Meteorological Observatory; since it is not operated by NWS persornel, it is classified as a second-order NWS station. The SSAP tower is operated for the Federal Aviation Administration, also under contract. The WSCP stat on was operated under contract by Shell Engineering and Associates, Inc., for Bechtel National for a 33-month period (December 1965 through April 1983). The LPP towers are operated by Union Electric personnel. RAMS station 125 was operated for a 30-month period in the mid-1970s as a part of a 25-station research network established by EPA under the Regional Air Pollution Study.

The nearest source for upper air data is the NWS station at Salem, Illinois, which is about $100 \mathrm{mi}$ east of Weldon Spring. The data were collected through twice-daily rawinsonde releases (i.e., tracking of a balloon by radio or radar). In November 1988, the Salem station was relocated to Paducah, Kentucky, which is closer to the site. The next closest source for upper air data is the station in Monett, Missouri, about $200 \mathrm{mi}$ southwest of Weldon Spring.

The sites were visited to compare topographic features at the five meteorological suriace station sites with those in and around the WSQ, WSCP, and general area of the proposed haul road. The LIAP, LPP-100, and SSAP meteorological surface stations 


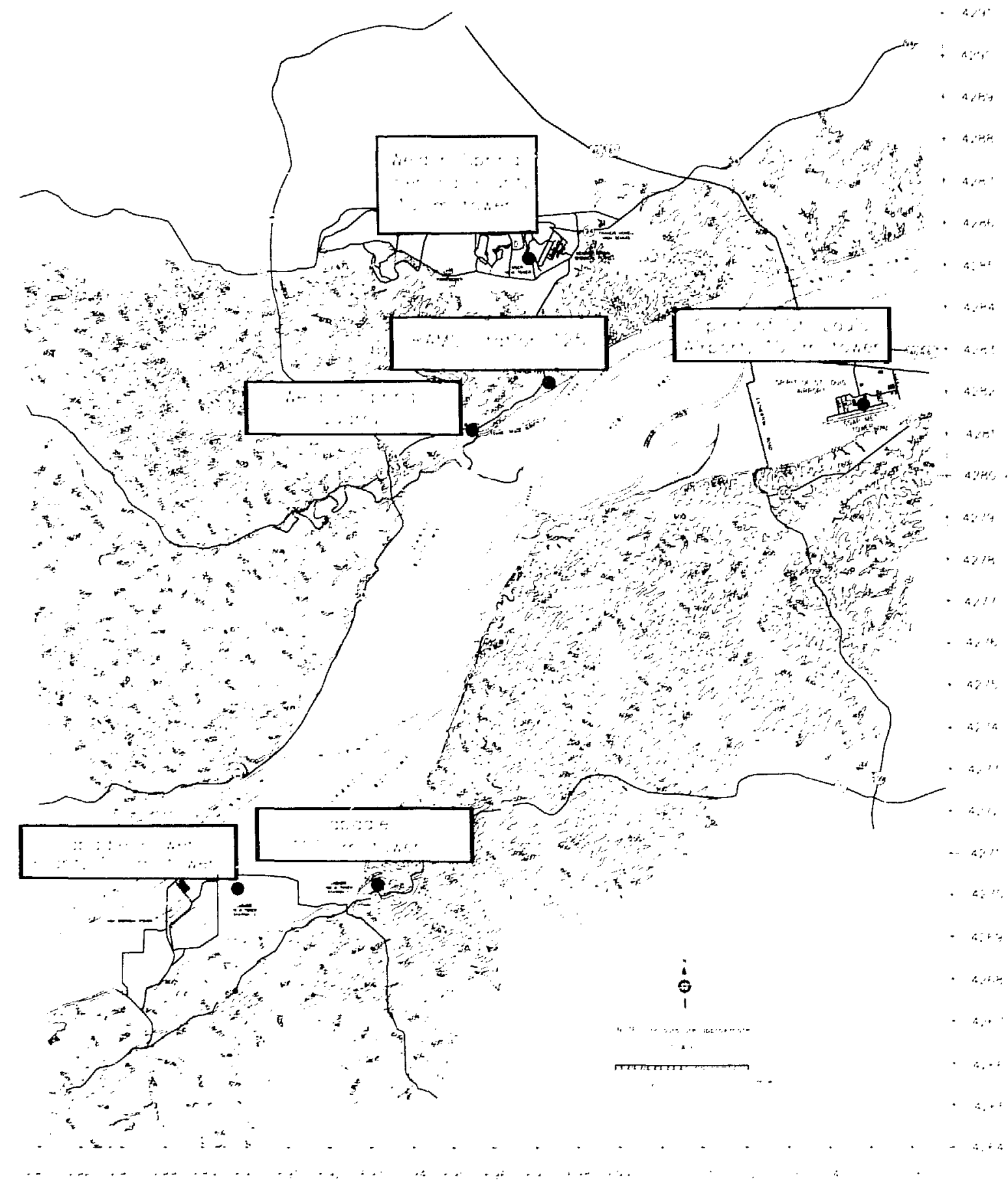

FIGURE 2 Topographic Map of the Weldon Spring Area Showing the Locations of Four Weather Stations Examined in This Study (coordinate system is Universal Transverse Mercatur [UTM]) (Source: Based on Refs. 9-12) 


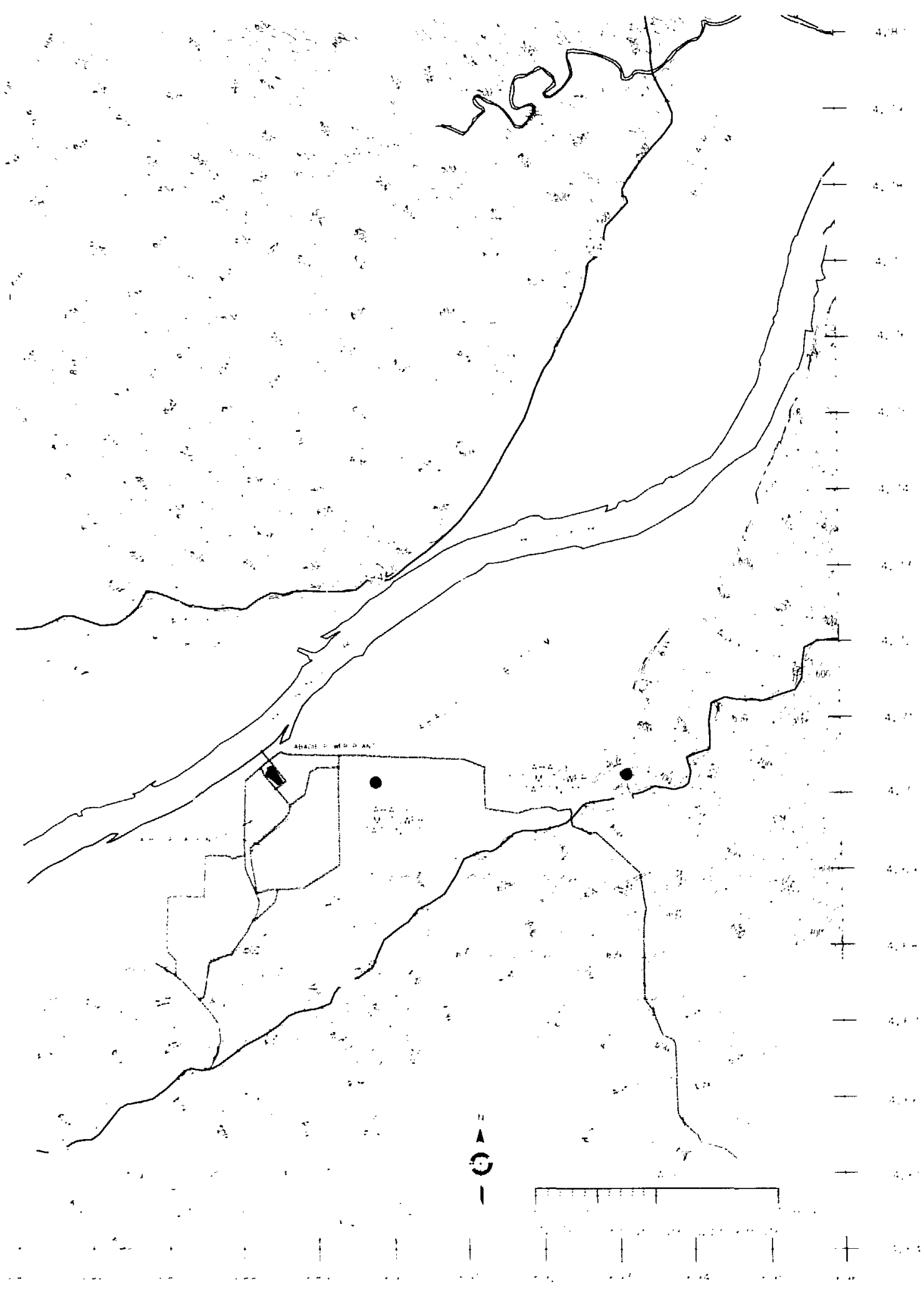

FIGURE 3 Topography Near the Labadie Power Plant (grid is UTM) (Source: Based on Refs. 9-12) 


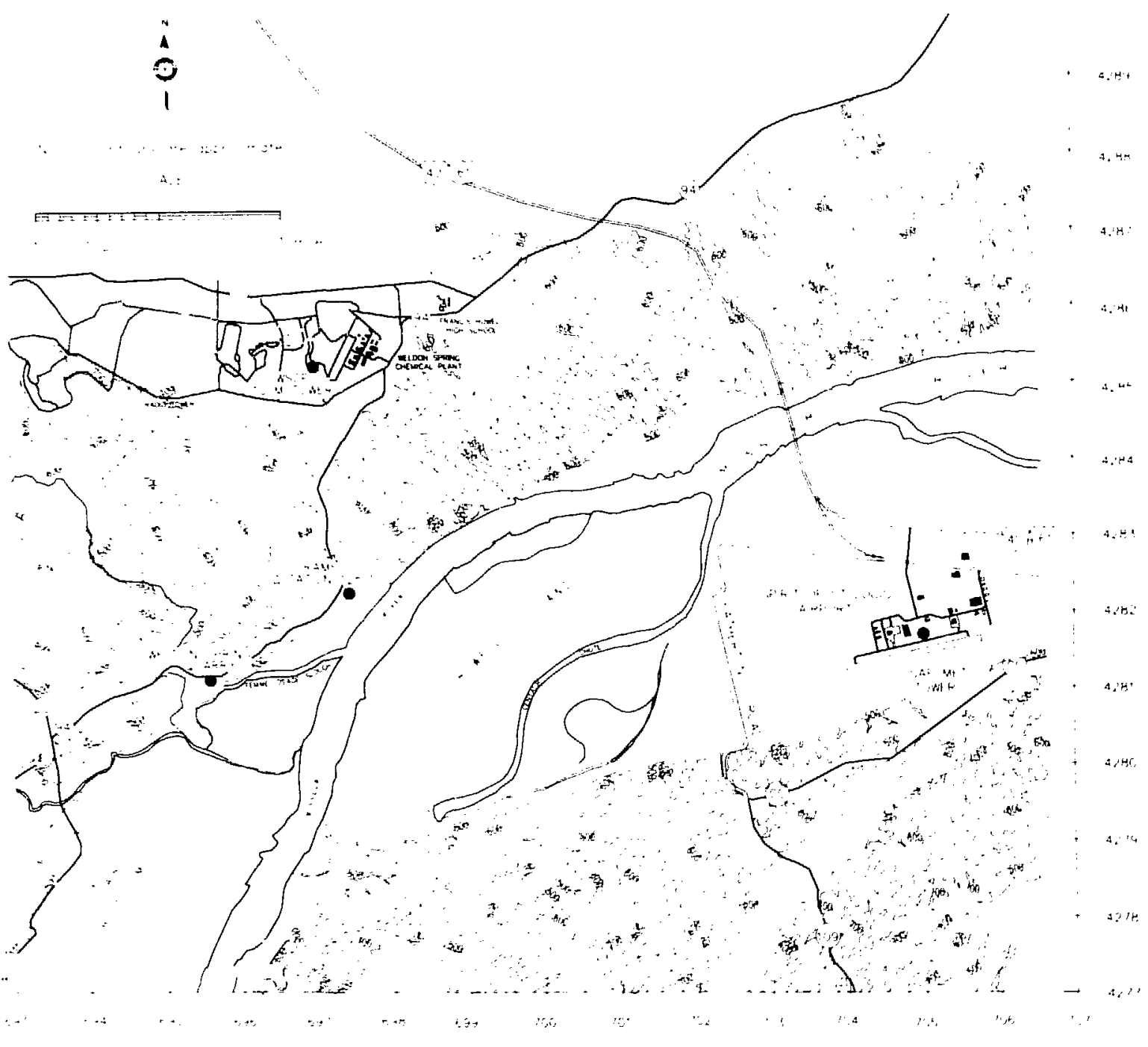

FIGURE 4 Topography Near the Weldon Spring Chemical Plant and Quarry, Spirit of St. Louis Airport, and Regional Air Monitoring Station 125 (grid is UTM)

(Source: Based on Refs. 9-12)

were visited to observe and record instrument exposure and site terrain (see Fig. 5). The general locations of the former WSCP, LPP-10, and RAMS surface stations were noted, although operations at these stations were phased out in January 1966, October 1966, and July 1977 , respectively, and the stations no longer exist. (See Fig. 6 for photographs of the WSCP station site and Missouri River Valley.) In addition to the observations made during the site visits, data on the terrain features (i.e., elevation, grade, land use) and the relative locations of the surface stations were obtained from USGS topographic maps. 
TABLE 1 Locations and Terrain Features of the Alternative Surface Weather Station Sites

\begin{tabular}{|c|c|c|c|c|c|}
\hline \multirow[b]{2}{*}{ Station Name } & \multirow{2}{*}{$\begin{array}{l}\text { UTM } \\
\text { Coor- } \\
\text { dinates }\end{array}$} & \multirow{2}{*}{$\begin{array}{l}\text { Approx. } \\
\text { Base E! e- } \\
\text { vation } \\
\text { (ft) }\end{array}$} & \multicolumn{2}{|c|}{$\begin{array}{l}\text { Distance and } \\
\text { Direction from: }\end{array}$} & \multirow[b]{2}{*}{ Terrain Characteristics } \\
\hline & & & WSQ $^{\mathbf{a}}$ & WSCP & \\
\hline $\begin{array}{l}\text { Lambert International } \\
\text { Airport, 10-m lower } \\
\text { (LIAP), St. Louis }\end{array}$ & $\begin{array}{r}729.7 \\
4291.7\end{array}$ & 540 & $\begin{array}{l}36 \mathrm{~km}, \\
\text { ENE }\end{array}$ & $\begin{array}{l}32 \mathrm{~km}, \\
\text { ENE }\end{array}$ & Gently rolling tis east and south \\
\hline $\begin{array}{l}\text { Weldon Spring Chemical } \\
\text { Plant, 10-m co:ser } \\
\text { (WSCP), Weldon Spring }\end{array}$ & $\begin{array}{l}697.00 \\
4285.20\end{array}$ & 650 & $\begin{array}{l}5 \mathrm{~km}, \\
\text { NNE }\end{array}$ & $\begin{array}{l}\text { On- } \\
\text { sit }=\end{array}$ & $\begin{array}{l}\text { Grade around WSCP less steep than } \\
\text { that between plant and WSQ, south } \\
\text { of heavily wooded Busch Memorial } \\
\text { Wildlife Area, elevation is about } \\
200 \mathrm{ft} \text { above that at quarry }\end{array}$ \\
\hline $\begin{array}{l}\text { Labadie Power P } 1 \text { ant } \\
\text { 10-m tower (LPP-10) }\end{array}$ & $\begin{array}{l}689.80 \\
4270.15\end{array}$ & 465 & $\begin{array}{l}16 \mathrm{~km}, \\
\mathrm{SSW}\end{array}$ & $\begin{array}{l}16.4 \mathrm{~km}, \\
\mathrm{NE}\end{array}$ & $\begin{array}{l}\text { In river valley on flat or gently } \\
\text { rolling terrain }\end{array}$ \\
\hline $\begin{array}{l}100-m \text { tower, } 50- \\
\text { and } 85-m \text { levels } \\
(L P P-100)\end{array}$ & $\begin{array}{l}693.15 \\
4270.25\end{array}$ & 700 & $\begin{array}{l}12.2 \mathrm{~km} \text {, } \\
\text { NNE }\end{array}$ & $\begin{array}{l}12.5 \mathrm{~km} \text {, } \\
\mathrm{SSW}\end{array}$ & $\begin{array}{l}\text { On ridge above valley in } \\
\text { moderately rough terrain }\end{array}$ \\
\hline $\begin{array}{l}\text { Spirit of St. Louis Airport, } \\
10-\mathrm{m} \text { tower }(58-\mathrm{m} \text { level) } \\
\text { (SSAP), Chesterfield }\end{array}$ & $\begin{array}{r}705.00 \\
4281.70\end{array}$ & 460 & $\begin{array}{l}9.5 \mathrm{~km}, \\
\mathrm{E}\end{array}$ & $\begin{array}{l}8.5 \mathrm{~km}, \\
\mathrm{SE}\end{array}$ & In river valley on flat terrain \\
\hline $\begin{array}{l}\text { Regional Air Monitoring } \\
\text { System, Station } 125, \\
30-m \text { tower (RAMS), Hamburg }\end{array}$ & $\begin{array}{l}697.44 \\
4282.24\end{array}$ & 613 & $\begin{array}{l}2.2 \mathrm{~km}, \\
\mathrm{SSE}\end{array}$ & $\begin{array}{l}3.4 \mathrm{~km}, \\
\mathrm{~s}\end{array}$ & $\begin{array}{l}\text { Near proposed haul road, just } \\
\text { west of State Route } 94 \text { and } 0.5 \mathrm{~km} \\
\text { west of river, wooded rolling } \\
\text { terrain with a } 267-\mathrm{ft} / \mathrm{km} \text { grade } \\
\text { to river }\end{array}$ \\
\hline
\end{tabular}

${ }^{a}$ The Weldon Spring quarry is located at coordinates 695.30 and 4281.30 at an elevation of about $540 \mathrm{ft}$. 

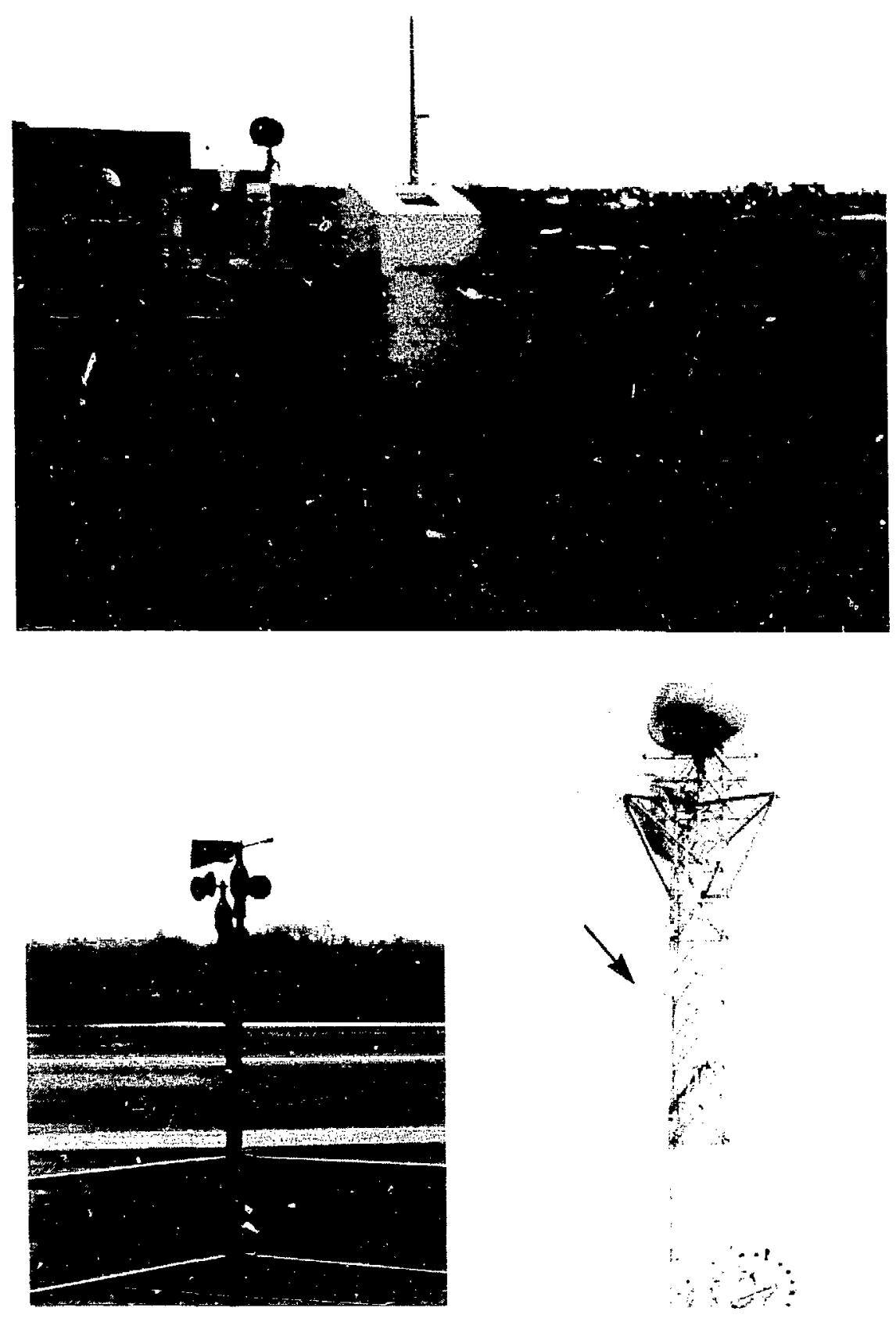

FIGURE 5 Views of the LIAP, SSAP, and LPP-100 Stations. Upper: LIAP Surface Weather Station (10-m tower not shown). Lower lefi: SSAP 10-Meter Tower. Lower right: Instruments (arrow) at the LPP-100 85-Meter Level. 

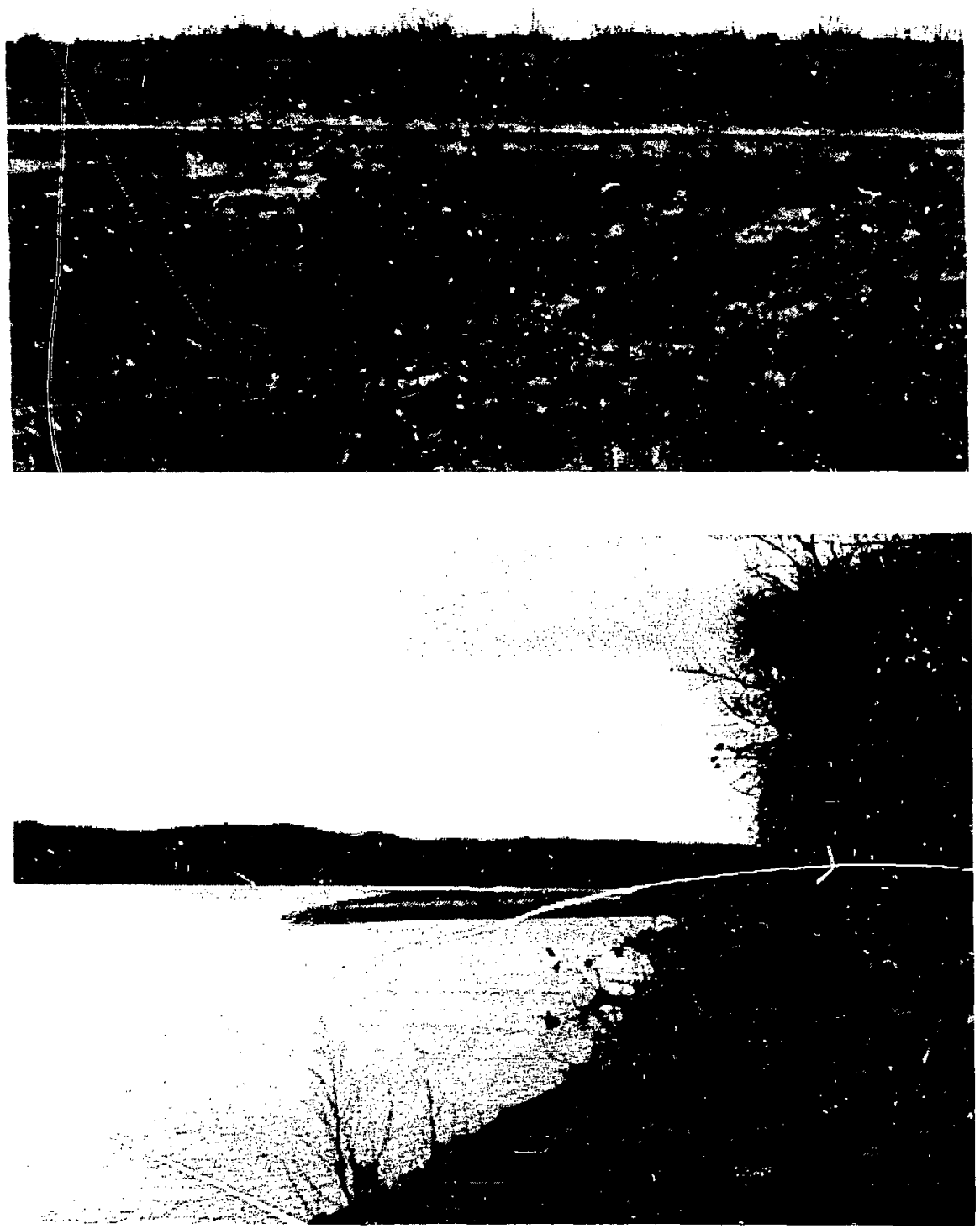

FIGURE 6 Views of the Welcien Spring Site. Upper: View of the Location of the Former WSCP Station (which is also the proposed TSA location). Lower: View of the Missouri River Valley near the Weldon Spring Quarry. 
The general geographic features in the vicinity of the quarry and chemical plant can be described as heavily wooded and hilly river valley terrain. The terrain south of the quarry gradually drops off into the broad, flat Missouri River floodplain. The proposed TSA has an elevation about $170 \mathrm{ft}$ higher than that at the WSQ. The terrain between the TSA and WSQ is characterized by a heavily wooded wilderness area with several areas of fairly steep surface features. The rim of the WSQ is near the ridge of the Missouri River Basin, about $90 \mathrm{ft}$ above the river surface. As discussed above, such terrain characteristics can have significant influences on wind flow patterns and on atmospheric stability, which play an important role in pollutant transport and dispersion. Site-specific (ori-site) or representative data are imperative to credible modeling.

\subsection{AVAILABLE DATÁ}

Table 2 lists the periods of record and the data collected for each of the five alternative meteorological surface stations. Digitized data on magnetic tape or floppy disks were available only for the LIAP station; a somewhat restricted comparison of alternative site data was provided by the WSCP and LPP-10 stations. Despite the limitations of this data set, the three sites with computer-formatted data provided a reasonable cross section. Data in other forms (i.e., microfiche and computer printout) were used to the extent possible.

Those instruments observed during the site visits met EPA's guidance for siting (i.e., horizontal and vertical probe placement) and exposure for on-site meteorological monitoring. ${ }^{13}$ Observations of instrument siting and exposure were not possible at four of the sites. One site (at LIAP) was located in a restricted area, and equipment at the other sites had been dismantled and removed af ter the monitoring program ended (WSCP, RAMS, and LPP-10 stations). Data recovery at the WSCP and LPP-10 stations was above $90 \%$ for each meteorological parameter and for the joint frenuency of parameters (winds and stability) only for one year, 1985.

\subsection{STABILI' 1 Y CLASSIFICATION}

Since neither cloud cover nor ceiling height data were recorded for the WSCP and LPP-10 stations, measures of $\sigma_{\phi}$ and $\sigma_{\theta}$ were used to determine the Pasquill stability categories. Table 3 illustrates this approceh, and Tables 4 and 5 present the results. ${ }^{13}$

Missing wind data (hourly values of wind speed and direction) at the LPP-10 station were replaced with corresponding winds measured at the SSAP station. Missing wind data at the WSCP station were replaced with corresponding wind data from the 50 or 85-m levels at the LPP-100 station. Where stability could not be determined due to missing $\sigma_{\phi}$ and $\sigma_{\theta}$ values at either station, data were substituted between stations for the missing hours. If data for the same hour were missing for both stations, then cloud cover and ceiling height data from the SSAP station were used with wind speed data to assign a stabiiity class. 
TABLE 2 Summary of Data Kecords for the Alternative Surface Weather Stations

\begin{tabular}{|c|c|c|c|c|c|c|c|}
\hline \multirow[b]{2}{*}{ Station } & \multirow[b]{2}{*}{ Period of Record ${ }^{a}$} & \multicolumn{6}{|c|}{ Data Collected ${ }^{b}$} \\
\hline & & $\bar{u}$ & $\mathrm{~T}$ & $\sigma_{\phi}$ & $\sigma_{\theta}$ & SI & $\Delta \mathrm{T}$ \\
\hline LIAP & $\begin{array}{l}1982-1986 \text { ( } 5 \text { yr of } \\
\text { stability array data) }\end{array}$ & $\mathrm{x}$ & $\mathrm{x}$ & - & - & $\mathrm{X}$ & - \\
\hline WSCP & $\begin{array}{l}\text { April } 1983- \\
\text { Dec. } 1985 \text { ( } 2.75 \text { yr } \\
\text { of irourly data) }\end{array}$ & $\mathrm{x}$ & $\mathrm{x}$ & - & $\mathrm{x}$ & - & - \\
\hline LPP-10 & $\begin{array}{l}\text { January } 1984- \\
\text { October } 1986(2.75 \text { yr } \\
\text { of hourly data })\end{array}$ & $x$ & $\mathrm{x}$ & $x$ & $\mathrm{x}$ & - & - \\
\hline $\begin{array}{l}\text { LPP-100 } \\
(50-\text { and } \\
85-\mathrm{m} \\
\text { levels })\end{array}$ & $\begin{array}{l}\text { May } 1983- \\
\text { December } 1987 \\
\text { (monthly frequency } \\
\text { distribution of } \\
\text { wincis) }\end{array}$ & $\mathrm{x}$ & $\mathrm{x}$ & - & $\mathrm{X}$ & $=$ & $x^{c}$ \\
\hline SSAP & $\begin{array}{l}\text { January } 1982- \\
\text { June } 1988(5.5 \text { yr } \\
\text { hourly microfiche } \\
\text { copy) }\end{array}$ & $\mathrm{x}$ & - & - & - & $\mathrm{x}$ & - \\
\hline RAMS 125 & $\begin{array}{l}\text { January } 1975- \\
\text { June } 1977(2.5 \mathrm{yr})\end{array}$ & $\mathrm{x}$ & $x$ & - & - & - & - \\
\hline \multicolumn{8}{|c|}{ 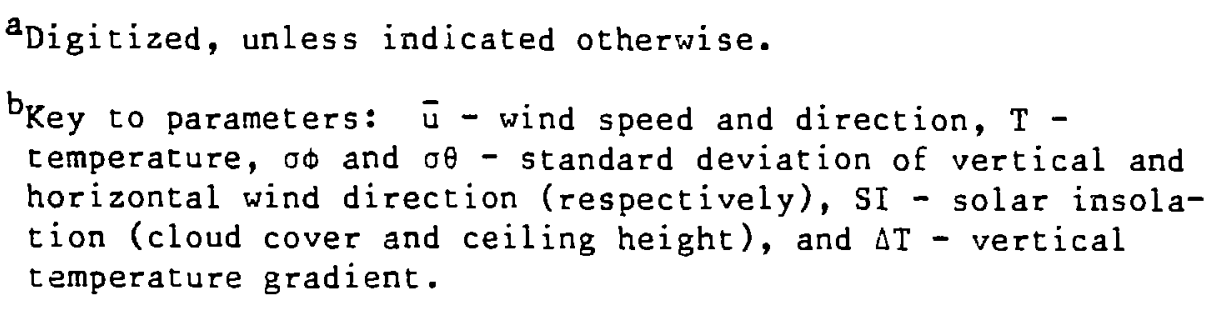 } \\
\hline \multicolumn{8}{|c|}{ 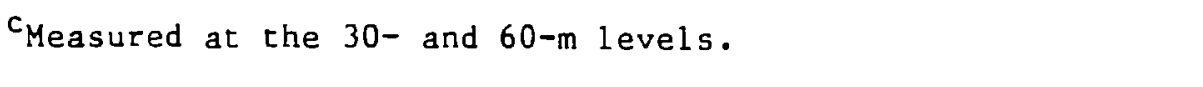 } \\
\hline Sources: & $\begin{array}{l}\text { Shell Engineering and } \\
\text { data and Union Electric }\end{array}$ & . & & & & & \\
\hline
\end{tabular}


TABLE 3 Initial Estimates of Pasquill Stability Categories

\begin{tabular}{llc}
\hline Cate- & \multicolumn{1}{c}{$\begin{array}{c}\text { Standard Deviation } \\
\text { of Wind Direction } \\
\text { Fluctuations } \\
\text { (degrees) }\end{array}$} \\
\hline A & Very unstable & $11.5 \leq \sigma$ \\
B & Moderately unstable & $10.0 \leq \sigma<11.5$ \\
C & Slightly unstable & $7.8 \leq \sigma<10.0$ \\
D & Neutral & $5.0 \leq \sigma<7.8$ \\
E & Slightly stable & $2.4 \leq \sigma<5.0$ \\
F & Moderately stable & \\
\hline
\end{tabular}

Source: Ref. 13, Table 6-5a. 
TABLE 4 Final Estimates of Pasquill Stability Categories for Vertical Wind Direction Fluctuations, Adjusting for Wind Speed

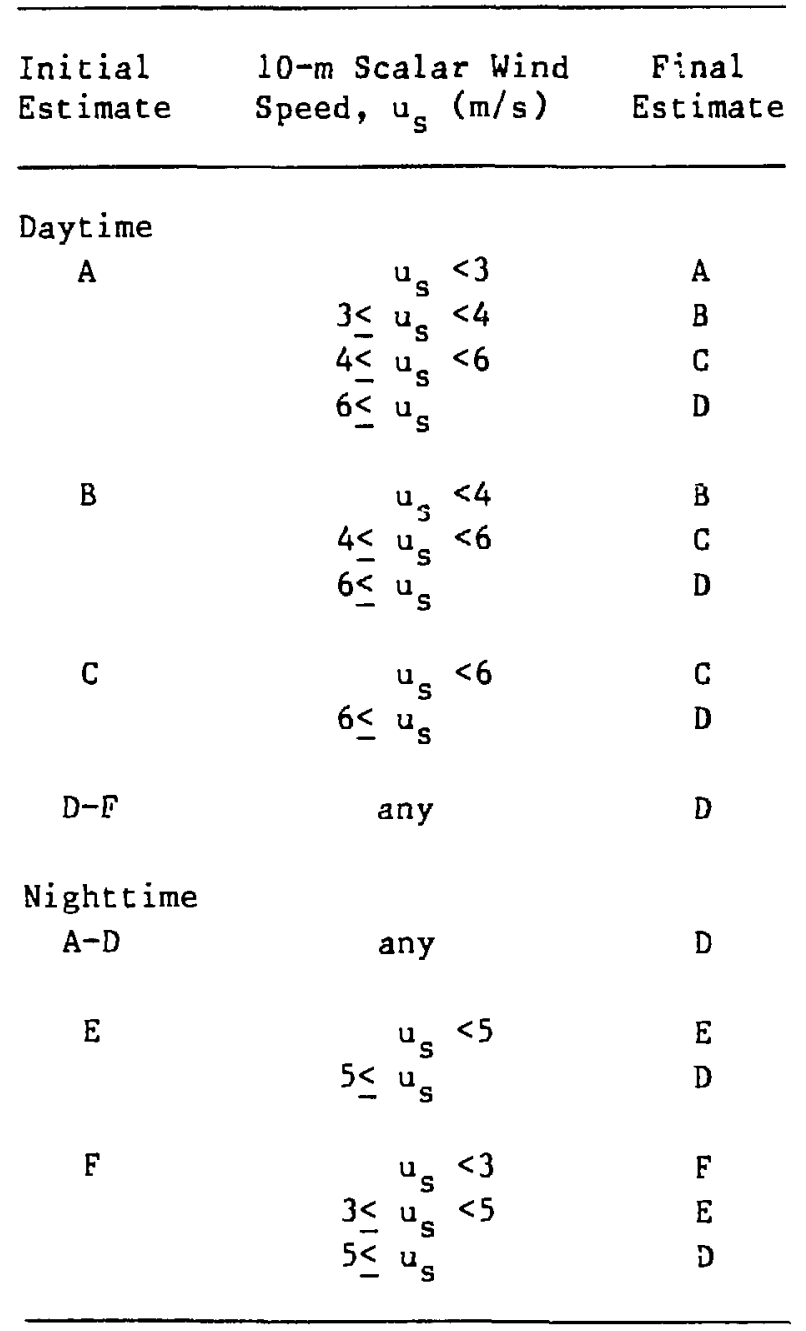

${ }^{a}$ Refer to Table 3 .

Source: Ref. 13, Table ó-5b. 
TABLE 5 Final Estimates of Pasquill Staibility Categories for Horizontal Wind Direction Fluctuations, Adjusting for Wind Speed ${ }^{\mathrm{a}}$

\begin{tabular}{|c|c|c|}
\hline $\begin{array}{l}\text { Initial } \\
\text { Estimate }\end{array}$ & $\begin{array}{l}\text { 10-m Scalar wind } \\
\text { Speed, } u_{s}(\mathrm{~m} / \mathrm{s})\end{array}$ & $\begin{array}{l}\text { Final } \\
\text { Estimate }\end{array}$ \\
\hline \multicolumn{3}{|l|}{ Daytime } \\
\hline \multirow[t]{4}{*}{ A } & $u_{s}<3$ & A \\
\hline & $3 \leq u_{s}<4$ & $B$ \\
\hline & $4 \leq u_{s}<6$ & $C$ \\
\hline & $6 \leq u_{s}$ & $\mathrm{D}$ \\
\hline \multirow[t]{3}{*}{ B } & $u_{s}<4$ & B \\
\hline & $4 \leq u_{s}<6$ & $c$ \\
\hline & $6 \leq u_{s}$ & D \\
\hline \multirow[t]{2}{*}{ C } & $u_{s}<6$ & C \\
\hline & $6 \leq u_{s}$ & $D$ \\
\hline$D-F$ & any & D \\
\hline
\end{tabular}

Nighttime

A

$\begin{array}{rl}2.9 \leq u_{s}<2.9 & F \\ 3.6 \leq u_{s} & E \\ & D\end{array}$

B

$u_{s}<2.4 \quad F$
$2.4 \leq u_{s}<3.0 \quad E$

$3.0 \leq u_{s}$

C $u_{s}<2.4 \quad E$ $2.4 \leq u_{s}$ D

D any D

E

$$
5.0 \leq u_{s}<5.0 \quad \text { E }
$$

F

$$
\begin{array}{rl}
3.0 \leq u_{s}<3.0 & E \\
5.0 \leq u_{s}<5.0 & E \\
&
\end{array}
$$

${ }^{a}$ Refer to Table 3 .

Source: Ref, 13, Table 6-6. 


\section{RESULTS AND DISCUSSION}

To select a representative site, each station and its data were evaluated and compared to known conditions at the TSA; factors evaluated included wind distribution, terrain features, instrument exposure and siting, and data availability (parameters measured and completeness of record). A preliminary comparison of terrain and site proximity suggested that data from the former WSCP station (10-m tower) best represented conditions at the proposed TSA and that data from the former RAMS station or the LPP-10 station best represented conditions at th': quarry. Furthermore, the proximity of the former WSCP station to the proposed TSA qualifies it as an on-site station and a spatially representative reference site. A semiqualitative analysis was performed using the criteria described in Sec. 1.1 to determine the validity of these judgmeits.

\subsection{WIND FREQUENCY DISTRIBUTIONS}

Data from three of the weather stations (a total of four data collection sites) were used to generate wind roses for 1985 , the only year for which data recovery and joint frequency exceedes $90 \%$ (see Sec. 3.3). Figures 7-10 show the wind roses obtained from the data.

In 1985 , winds at all four sites had a strong south component (most frequent from that direction at the WSCP, LPP-100, and LIAP stations). West winds were most frequent at the LPP-10 station. Data from ten stations in the Regional Air Pollution Study network also indicate that winds within a $40-\mathrm{km}$ radius of downtown St. Louis are most frequently from the south. ${ }^{16}$ None of the EFA stations were located in river valley terrain similar to the terrain surrounding the LPP or SSAP. Stronger winds (more frequent occurrence of nigher wind speeds) were more evident at the LPP-10 site than at the WSCP site. The wind roses for the WSCP and the LPP-100 stations showed the closest similarity in wind flow among the four sites shown (the LPP-100 50-m level wind rose, which is not shown, also showed patterns similar to the WSCP and LPP-100 85-m level data). As would be expected, winds at the $85-\mathrm{m}$ level were much stronger than those at the $10-\mathrm{m}$ level at the WSCP, primarily due to surface friction effects. A powerlaw adjustment of the $85-\mathrm{m}$ level winds to the $10-\mathrm{m}$ level would make the difference in average wind speeds between sites smaller. However, comparison of average wind speeds at the WSCP station with average wind speeds at LPP-10 shows winds to be generally weaker at the WSCP site, at least for 1985 . This may be due to the difference in surface friction effects between the relatively flat LPP-10 floodplain site and the generally more wooded and rougher WSCP site.

Figures 11 and 12 show quarterly wind roses at the WSCP and the LPP-10 stations. South winds are predominant for all seasons at both sites, except for the winter and autumn quarters at LPP-10 (when west winds dominated). 


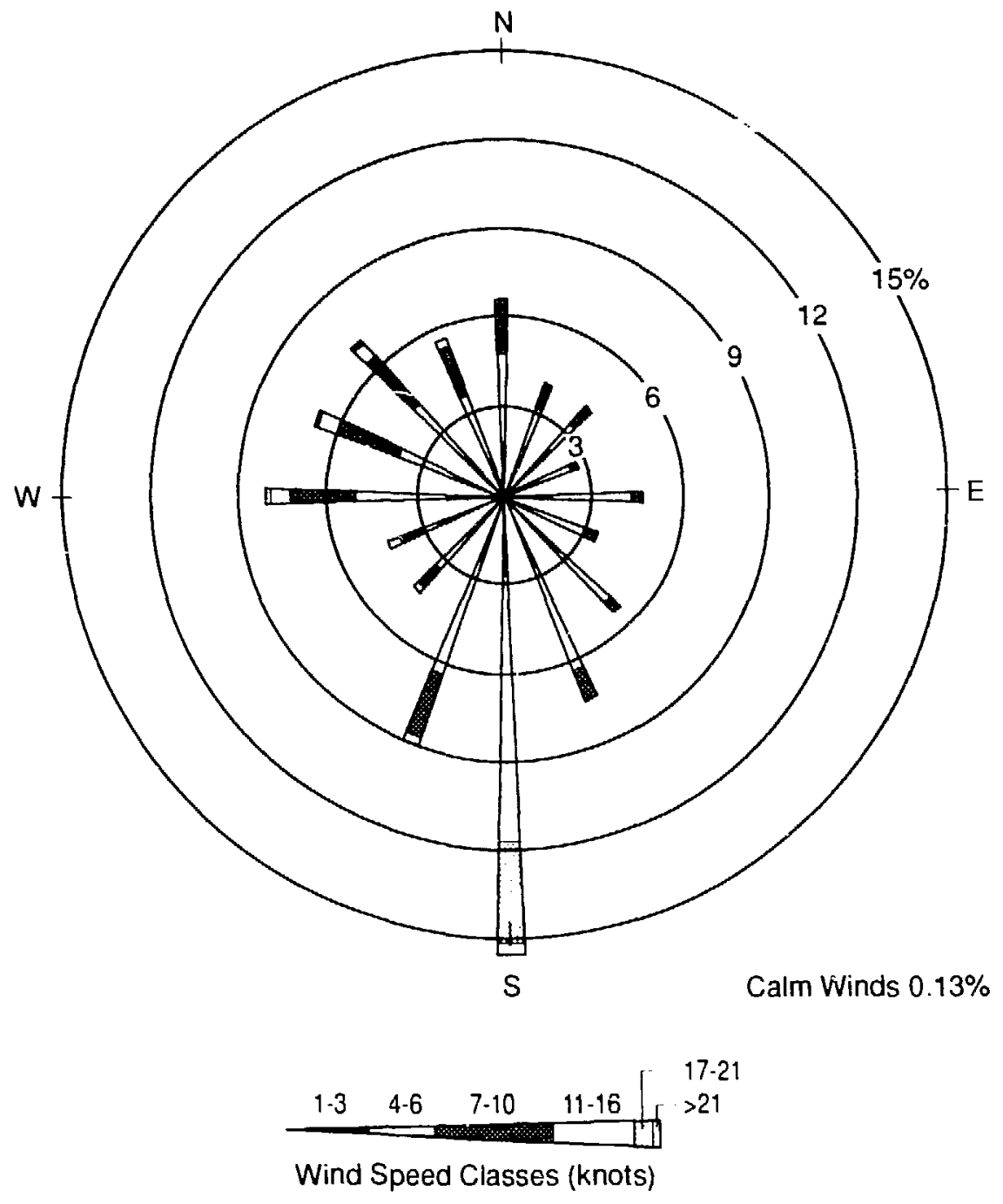

FIGURE 7 Wind Frequency Distribution at the WSCP Station During 1985 


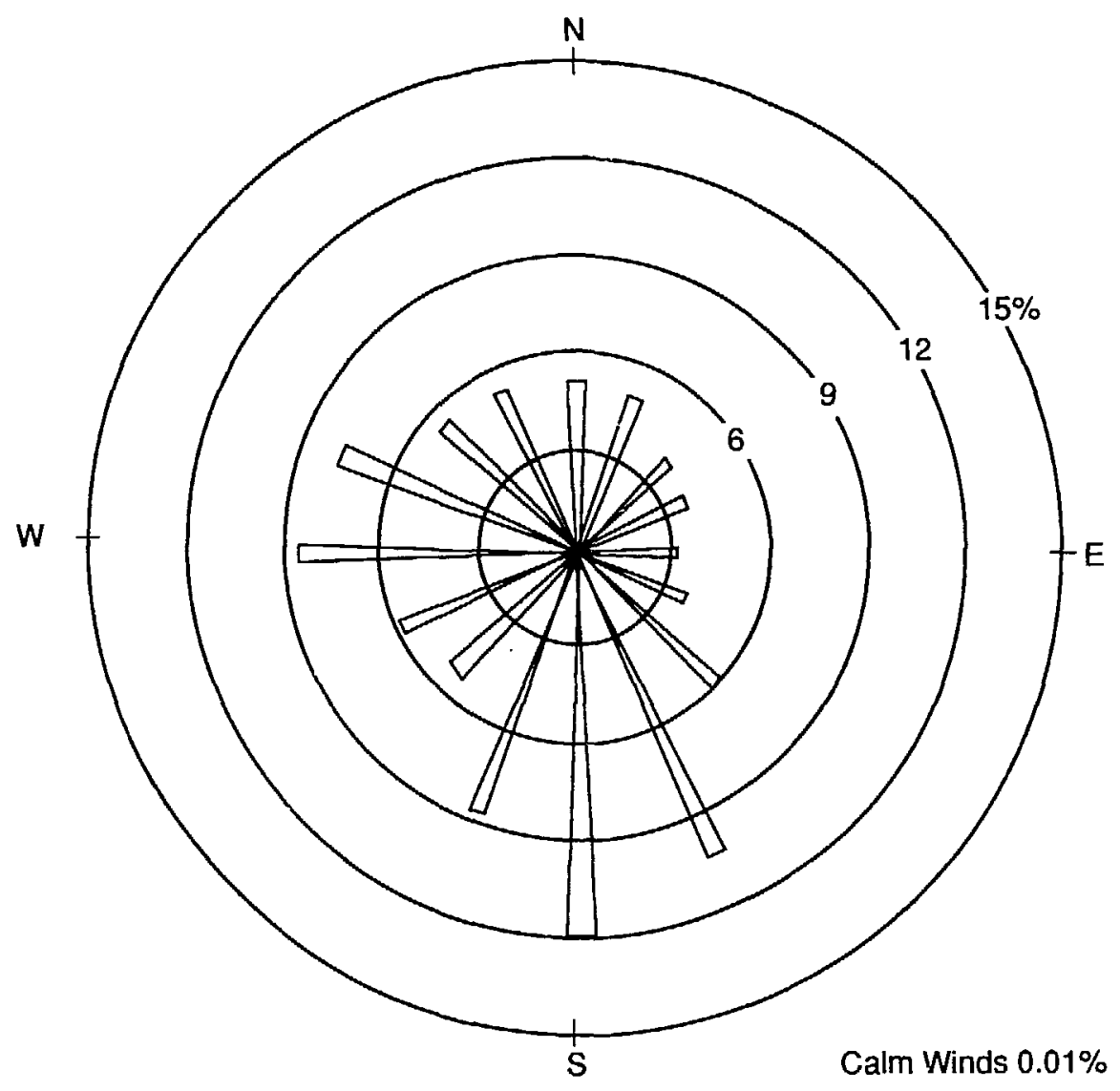

FIGURE 8 Wind Frequency Distribution at the L.PP-100 Station (85-m level) During 1985 (Calms as a function of wind speed class were not provided in the LPP-100 data base.) 


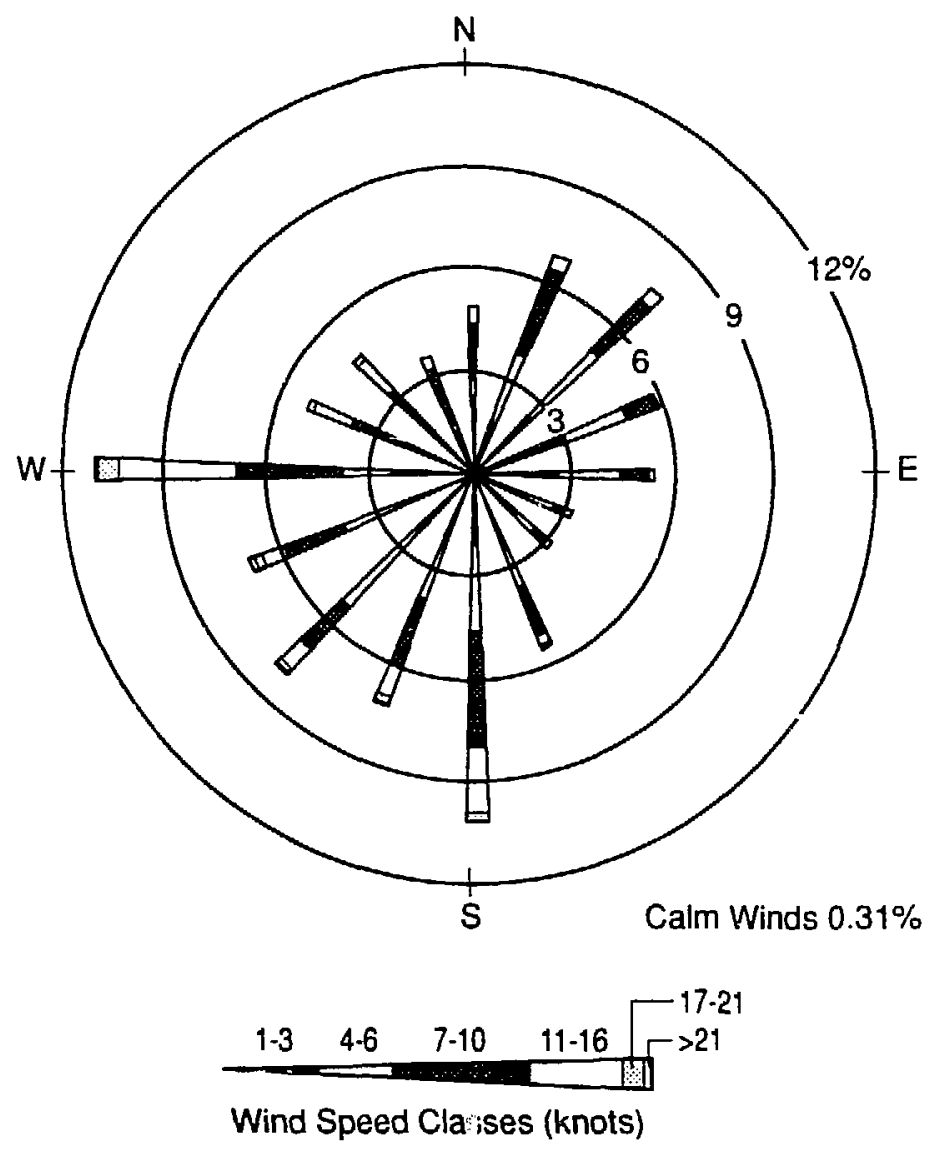

FIGURE 9 Wind Frequency Distribution at the LPP-10 Station During 1985 


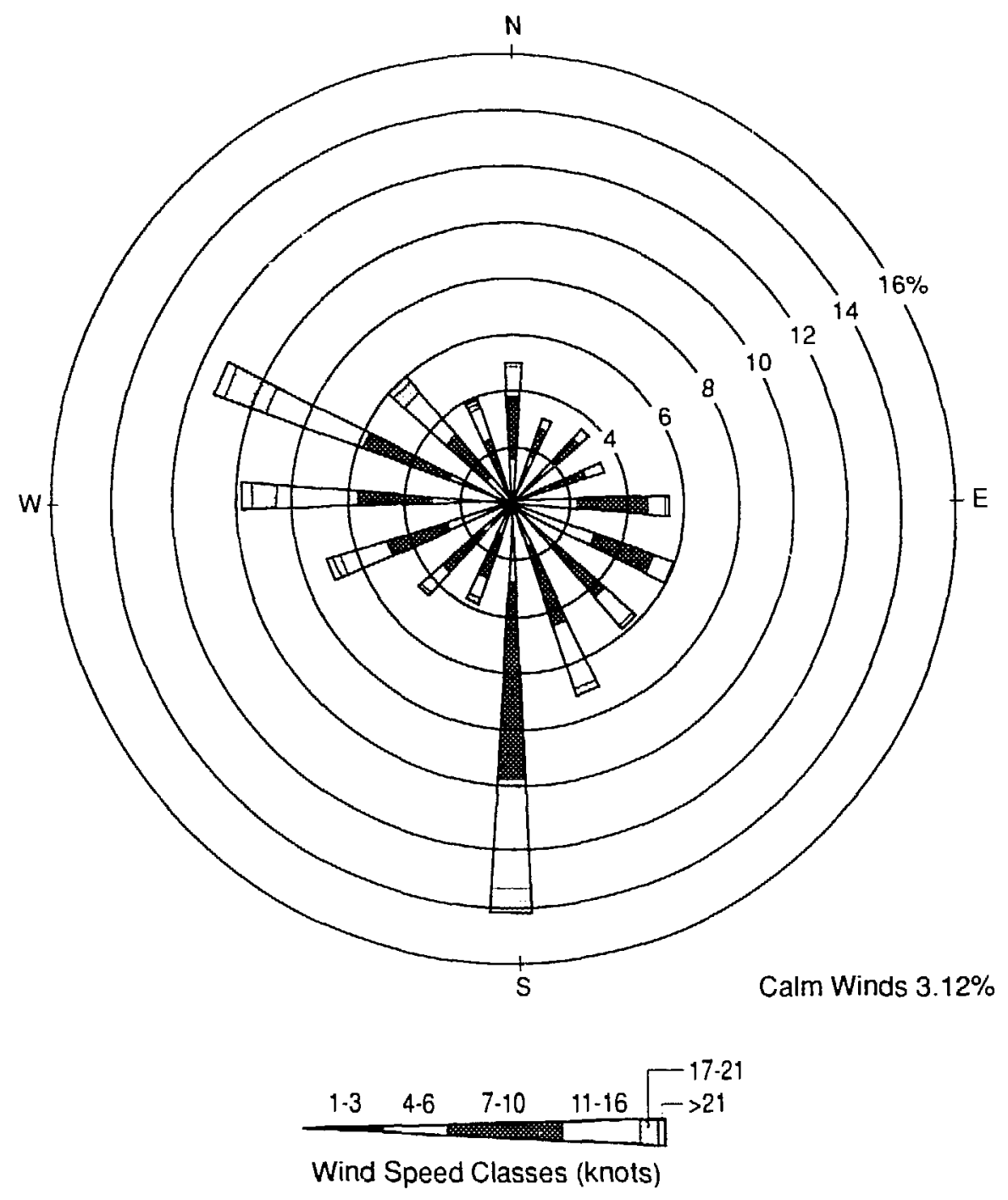

FIGURE 10 Wind Frequency Distribution at the LIAP Station During 1985 

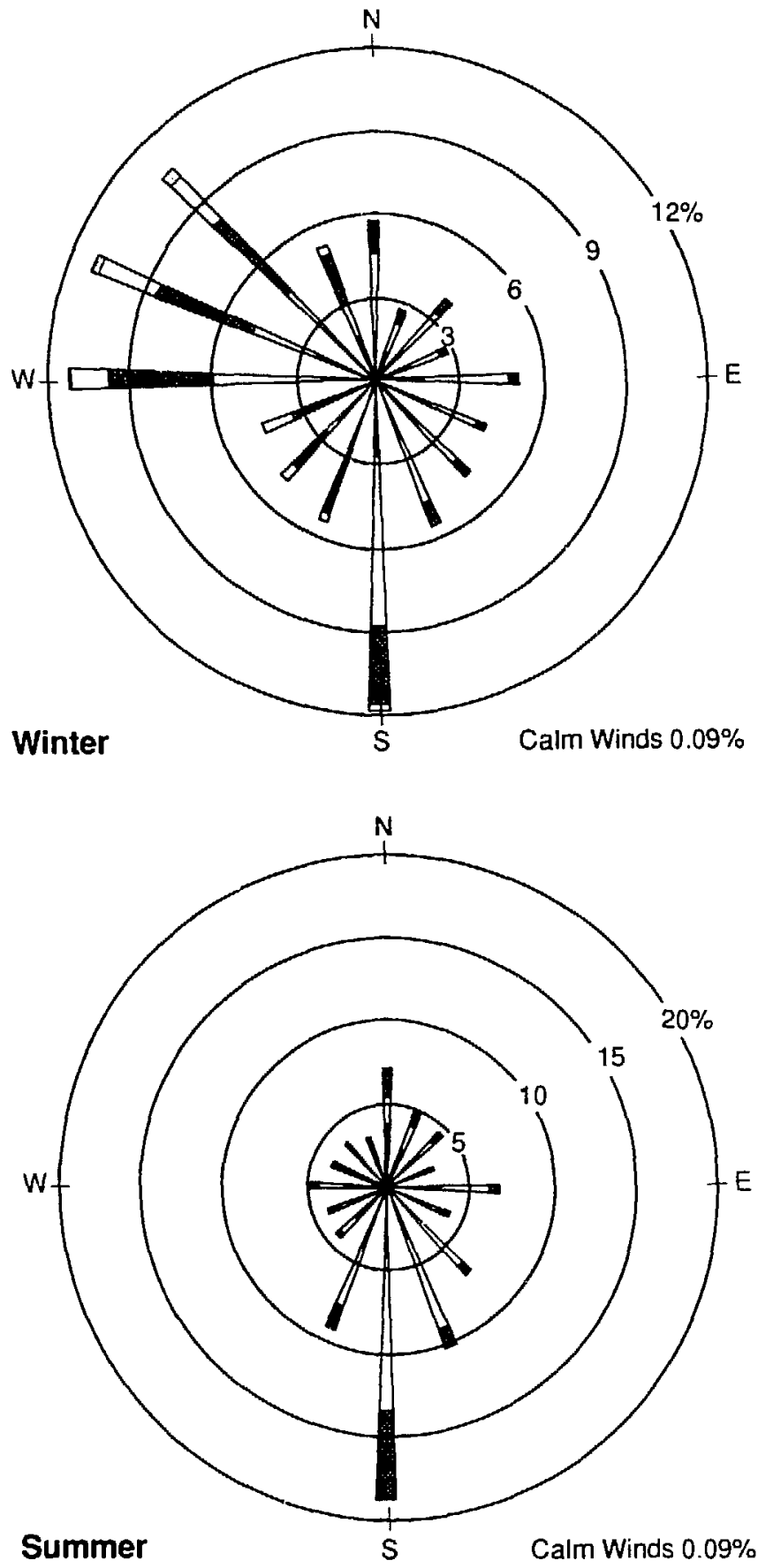

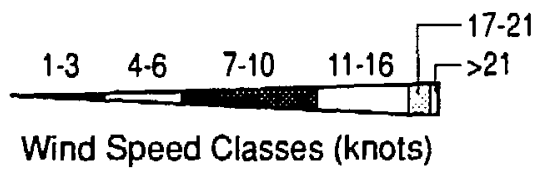

FIGURE 11 Seasonal Wind Frequency Distributions at the WSCP Station During 1985 

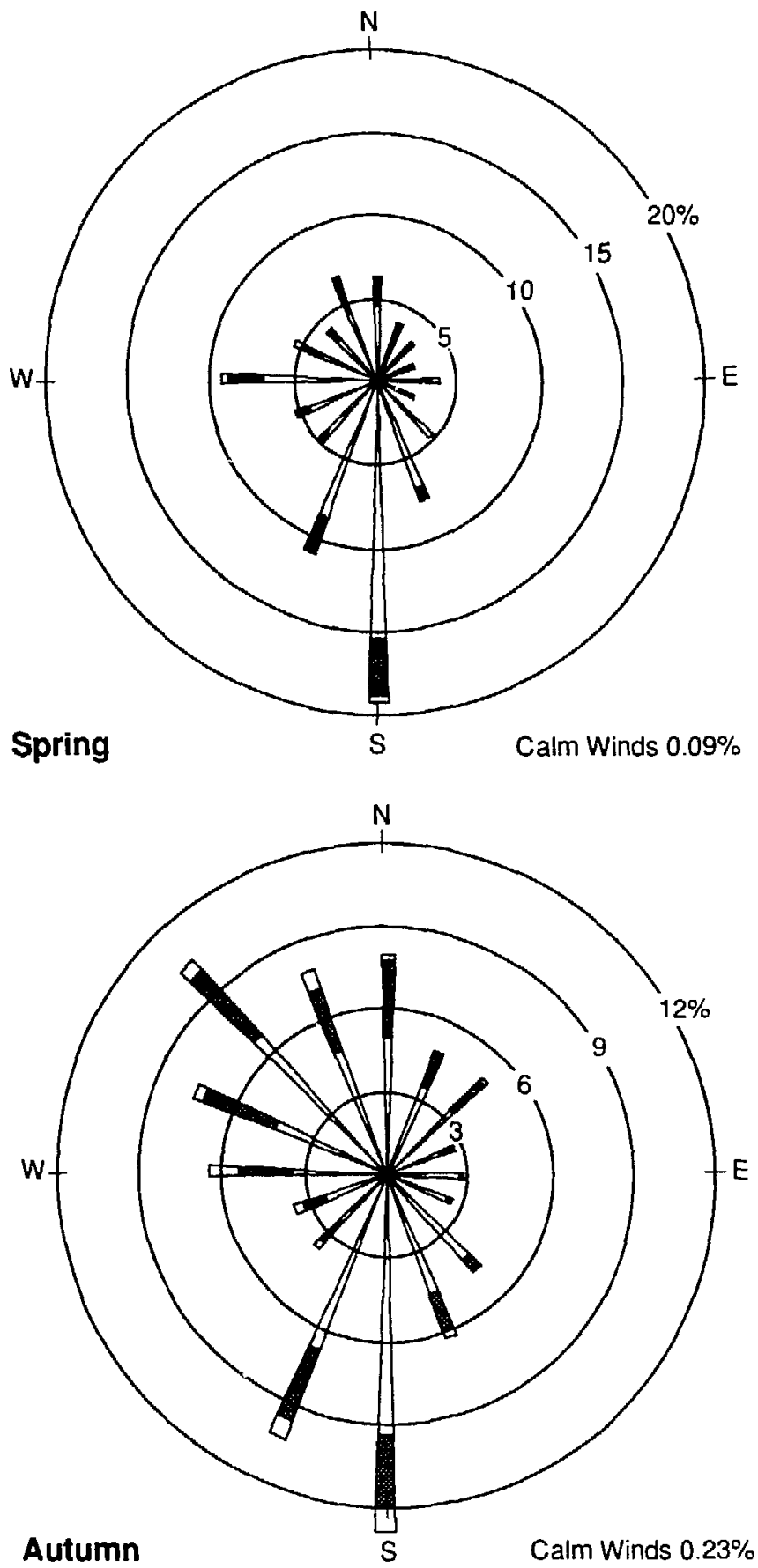

$$
\left.\begin{array}{llll}
1-3 \quad 4-6 \quad 7-10 & 11-16
\end{array}\right]-17-21
$$



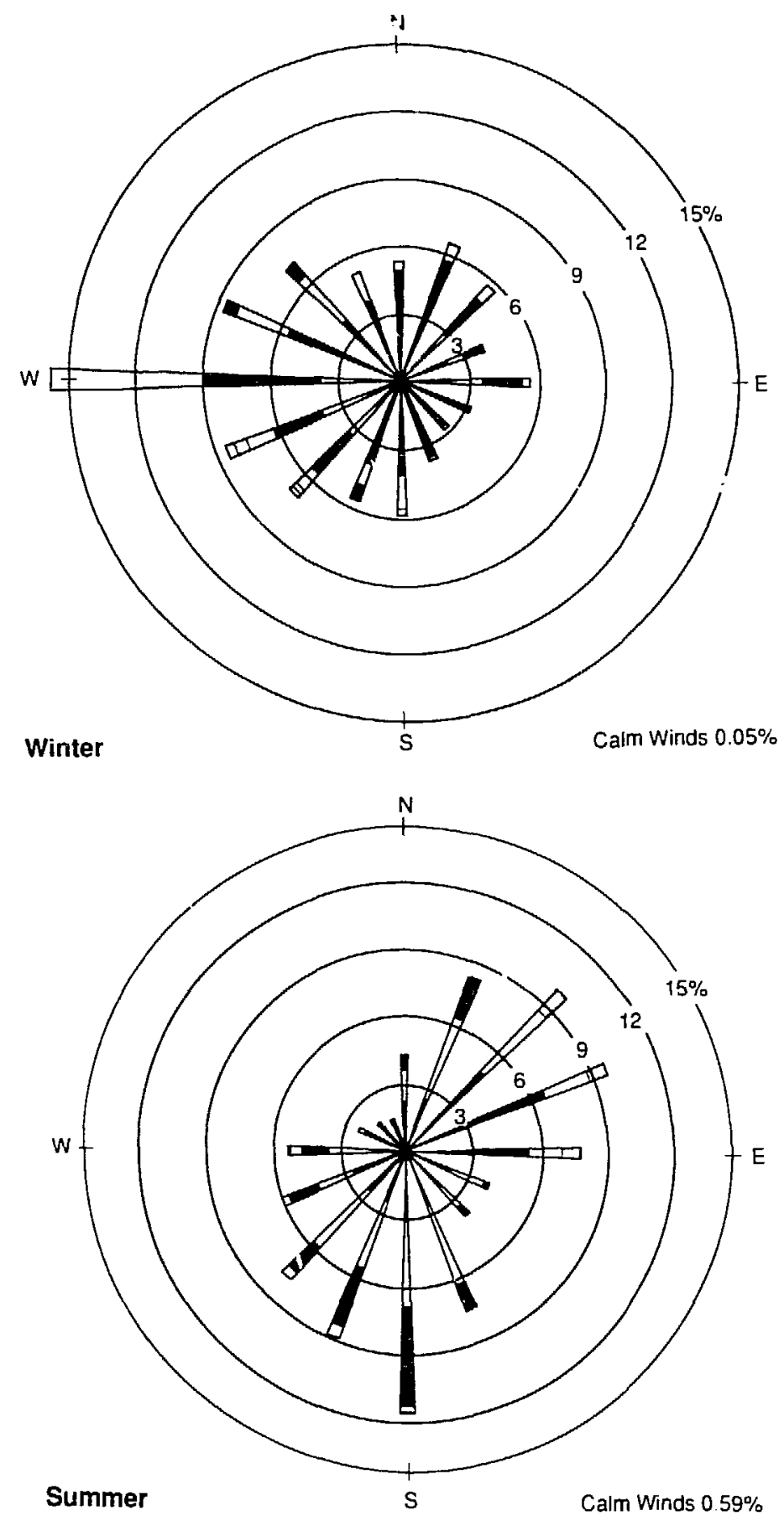

$\frac{1-3 \quad 46 \quad 7-10 \quad 11-16]}{\text { Wind Speed Classes (knots) }}{ }^{17-21}$

FIGURE 12 Seasonal Wind Frequency Distributions at the LPP-10 Station During 1985 

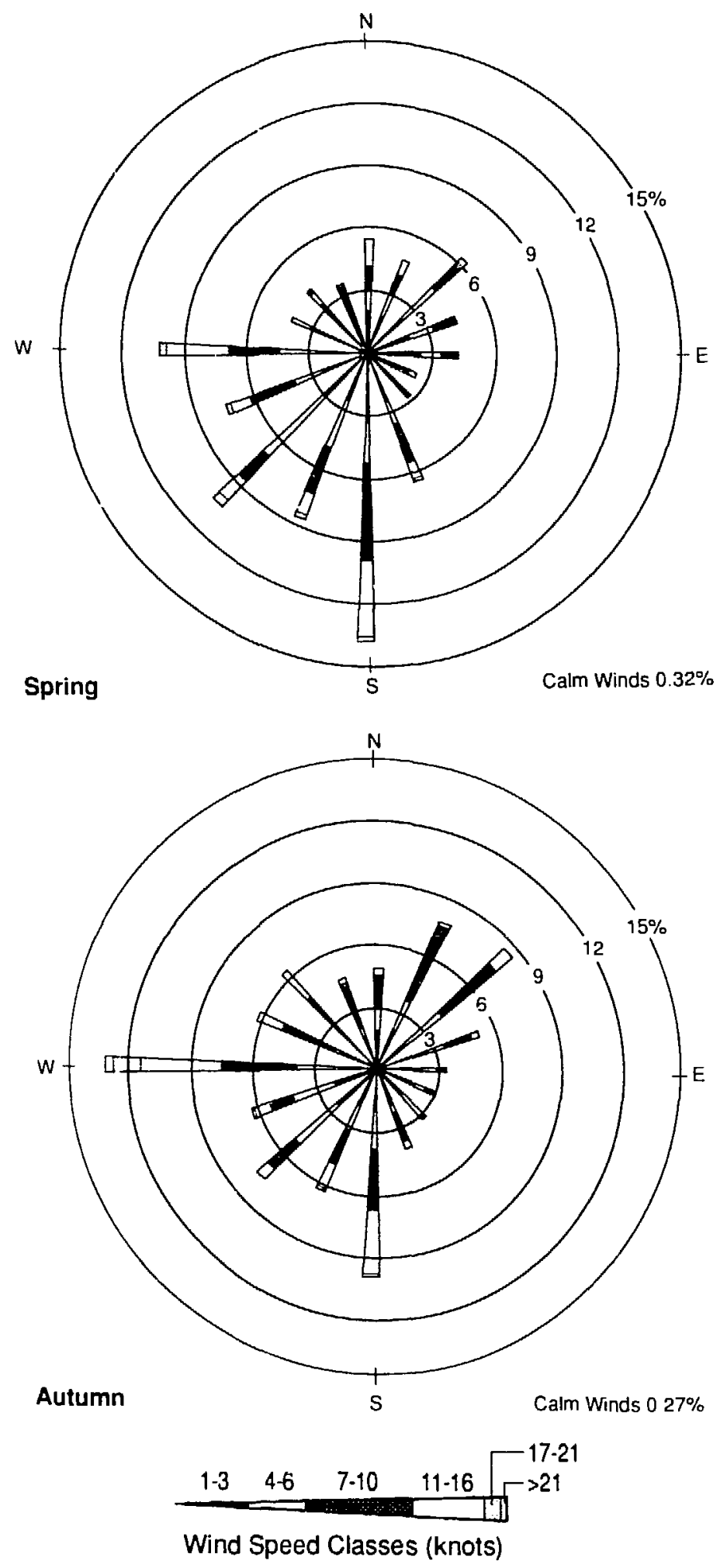

FIGURE 12 (Cont'd) 


\subsection{RANKING OF DATA SETS}

After completion of the above analysis, the data sets (i.e., each station or tower) were ranked as shown in Table 6, where the higher rankings are given to more representative data. Rankings were assigned based on six factorsi (1) location, (2) terrain features, (3) data recovery and completeness, (4) instrument exposure, (5) relative wind frequency distribution compared to the reference site, and (6) relative instrument elevation compared to the projected emission release height. The factors were weighted, according to the author's best judgment, as follows:

- Weighting of three -- proximity of the instrument and emission source,

- Weighting of two -- surrounding terrain and data recovery and completeness, and

- Weighting of one -- all other factors.

TABLE 6 Ranking of Data Set

Representativeness

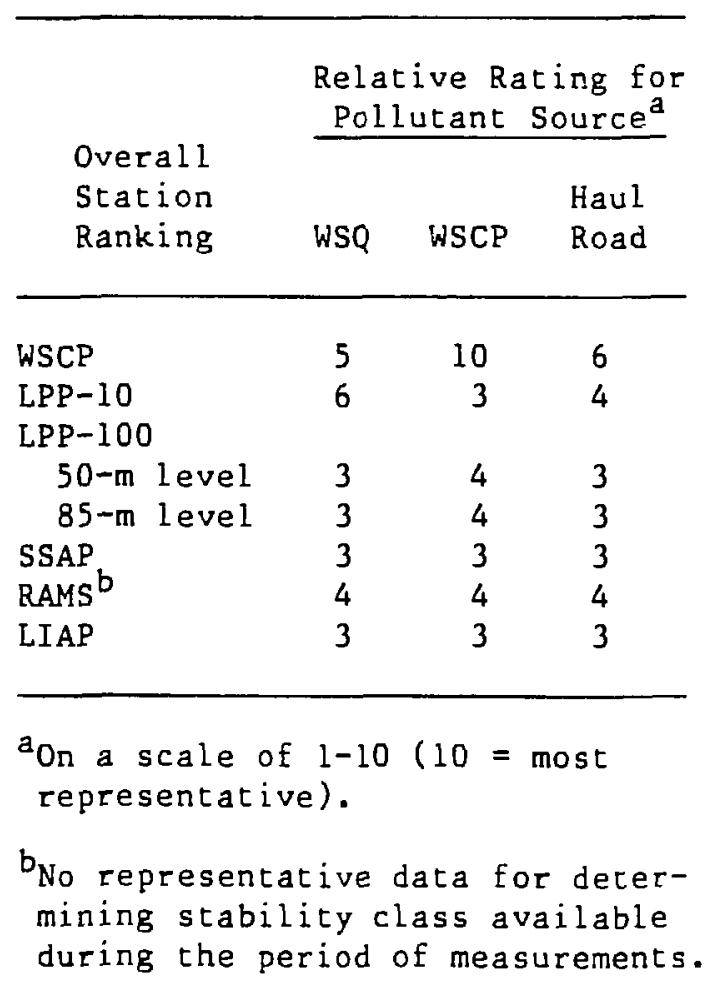




\section{RECOMMENDATION}

In general, this study found that the WSCP station data are most representative of meteorological conditions near the proposed TSA and that the LPP-10 station data are most representative of conditions near the WSQ. This study also found that the WSCP and LPP-100 (either level) data best represent wind patterns above the Missouri River Basin, while the SSAP and LPP-10 data best represent winds within the basin. The quarry is most likely to be influenced by valley basin winds due to its proximity to the basin rim.

Based on this analysis, the author recommends that air dispersion modeling of the WSCP emissions be conducted with measurements taken during 1985 at the WSCP surface meteorological station. The WSQ modeling should be done with the LPP-10 measurements, also taken during 1985. The haul road pollutant transport and dispersion conditions would be represented best by the WSCP 1985 data. These data should enable the most representative characterization of wind flow patterns for modeling transport and dispersion of pollutant emissions during the planned remedial activities at the Weldon Spring site (WSCP, WSQ, and haul road).

Data collected during 1985 from these sites should be used along with the climatological mixing heights determined from Holzworth ${ }^{17}$ or the twice-daily 1985 measurements of mixing heights at the Salem, lllinois, upper air station for the long-term and short-term modeling analysis, respectively. The author believes that the terrain relief at and around the Weldon Spring site is not significant enough to constrain the use, or invalidate the results, of a simple Gaussian dispersion model, such as the ISC model. 


\section{REFERENCES}

1. Geiger, R., The Climate Near the Ground, Chapters 18-20, Howard University Press (1959).

2. Yoshino, M.N., Climate in a Small Area, University of Tokyo Press (1975).

3. Davidson, B., and J. Halitsky, Studies of the Field of Turbulence in the Lee of Mountain Ridges and Tree Lines, New York University Press (1961).

4. Snyder, W.N., Similarity Criteria for the Application of Fluid Models to the Study of Air Pollution Meteorology, Boundary Layer Meteorology, 3:113-134 (1972).

5. Bergen, J.D., Cold Air Drainage on a Forested Mountain Slope, Journal of Applied Meteorolosy, 8:884-895 (1969).

6. Panofsky, H., and B. Prasad, Journal of Applied Meteorology, 6(3):493-499 (1982).

7. Defant, F., Local Wind, in Compendium of Meteorology, American Meteorological Society, Boston (1951).

8. Roberts, J.J., et al., Report to the U.S. EPA of the Specialist Conference on the EPA Modeling Guideline, prepared for the U.S. Environmental Protection Agency, Office of Air Quality Planning and Standards (Feb. 1977).

9. U.S. Geological Survey, Weldon Spring, Mo., 7.5-Minute Series, Map DMA 7861 II NW - Series V879 (1954; photorevised 1982).

10. U.S. Geological Survey, Eureka, Mo., 7.5-Minute Series, Map DMA 7861 II SW Series V879 (1954; photorevised 1982).

11. U.S. Geological Survey, Defiance, Mo., 7.5-Minute Series, Map AMS 7861 III NE Series V879 (1972; photoinspected 1979).

12. U.S. Geological Survey, Labadie, Mo., 7.5-Minute Series, Map DMA 7861 III SE Series V879 (1972; photoinspected 1980).

13. On-Site Meteorological Program Guidance for Regulatory Modeling Applications, U.S. Environmental Protection Agency Report EPA-450-78-027R (June 1987).

14. Guideline on Air Quality Models (Revised), U.S. Environmental Protection Agency Report EPA-450/2-78-027 R (July 1986; supplement dated July 1987).

15. Turner, D.B., Relationships between 24-hour Mean Air Quality Measurements and Meteorological Factors in Nashville Tennessee, J. Air Pollution Control Assoc., 11(10) (Oct. 1961). 
16. Trijonis, J., et al., Analysis of the St. Louis RAMS Ambient Particulate Data, U.S. Environmental Protection Agency Report EPA-450/4-60-006A (1980).

17. Holzworth, G.C., Mixing Heights, Wind Speeds, and Potential for Urban Air Pollution Throughout the Contiguous United States, U.S. Environmental Protection Agency Report AP-101 (Jan. 1972). 